\title{
Molecular database for classifying Shorea species (Dipterocarpaceae) and techniques for checking the legitimacy of timber and wood products
}

\author{
Yoshihiko Tsumura $\cdot$ Tomoyuki Kado $\cdot$ Kazumasa Yoshida $\cdot$ Hisashi Abe $\cdot$ Masato Ohtani $\cdot$ \\ Yuriko Taguchi $\cdot$ Yoko Fukue $\cdot$ Naoki Tani $\cdot$ Saneyoshi Ueno $\cdot$ Kensuke Yoshimura $\cdot$ Koichi Kamiya \\ Ko Harada · Yayoi Takeuchi · Bibian Diway • Reiner Finkeldey • Mohamad Na'iem • Sapto Indrioko • \\ Kevin Kit Siong Ng $\cdot$ Norwati Muhammad $\cdot$ Soon Leong Lee
}

Received: 28 April 2009/Accepted: 4 April 2010/Published online: 15 May 2010

(C) The Botanical Society of Japan and Springer 2010

\begin{abstract}
The extent of tropical forest has been declining, due to over-exploitation and illegal logging activities. Large quantities of unlawfully extracted timber and other wood products have been exported, mainly to developed countries. As part of the export monitoring effort, we have developed methods for extracting and analyzing DNA from wood products, such as veneers and sawn timbers made from dipterocarps, in order to identify the species from which they originated. We have also developed a
\end{abstract}

Electronic supplementary material The online version of this article (doi:10.1007/s10265-010-0348-z) contains supplementary material, which is available to authorized users.

Y. Tsumura $(\bowtie) \cdot$ T. Kado $\cdot$ K. Yoshida $\cdot$ H. Abe

M. Ohtani - Y. Taguchi $\cdot$ N. Tani - S. Ueno $\cdot$ K. Yoshimura

Department of Forest Genetics, Forestry and Forest Products

Research Institute, Tsukuba, Ibaraki 305-8687, Japan

e-mail: ytsumu@ffpri.affrc.go.jp

Y. Tsumura - Y. Fukue

Graduate School of Life and Environmental Sciences,

University of Tsukuba, Tsukuba, Ibaraki 305-8572, Japan

K. Kamiya $\cdot$ K. Harada

Faculty of Agriculture, Ehime University,

Matsuyama 790-8566, Japan

Y. Takeuchi

Center for Ecological Research, Kyoto University,

Hirano-cho, Otsu 520-2113, Japan

B. Diway

Forest Department Sarawak, Forest Research Center,

Sarawak, 93660 Kuching, Sarawak, Malaysia

R. Finkeldey

Institute of Forest Genetics and Forest Tree Breeding,

Georg-August University of Göttingen, Göttingen, Germany chloroplast DNA database for classifying Shorea species, which are both ecologically and commercially important canopy tree species in the forests of Southeast Asia. We are able to determine the candidate species of wood samples, based on DNA sequences and anatomical data. The methods for analyzing DNA from dipterocarp wood products may have strong deterrent effects on international trade of illegitimate dipterocarp products. However, the method for analyzing DNA from wood is not perfect for all wood products and need for more improvement, especially for plywood sample. Consequently, there may be benefits for the conservation of tropical forests in Southeast Asia.

M. Na'iem · S. Indrioko

Faculty of Forestry, Gadjah Mada University,

Bulaksumur, Yogyakarta 55281, Indonesia

K. K. S. Ng · N. Muhammad · S. L. Lee

Forest Research Institute Malaysia, 52109 Kepong,

Selangor, Malaysia

Present Address:

T. Kado

Hayama Center for Advanced Studies,

Graduate University for Advanced Studies,

Hayama, Kanagawa 240-0193, Japan

Y. Fukue

Forestry Research Institute, Oji Paper Company Limited,

24-9 Nobono-cho, Kameyama, Mie 519-0212, Japan

N. Tani

Japan International Research Center for Agricultural Sciences,

Ohwashi, Tsukuba 305-8686, Japan 
Keywords cpDNA - Conservation - Database . Tropical forest · Illegal logging · Southeast Asia

\section{Introduction}

The importance of conserving biodiversity is increasingly recognized globally, especially since the Convention on Biological Diversity was adopted in 1992 (Balmford et al. 2005). The developing countries in Southeast Asia have concerns about losses of their biological resources and strong motives to ensure that they are sustainably used. However, valuable plant resources are still being illegally extracted and taken to other countries. Certification of sustainable forestry and environmental conservation activities have recently started in these countries (Viana et al. 1996), which can significantly help to reduce illegal logging activities. However, introducing effective implementation of forest certification programs in all of these countries will take considerable time and, until then, tropical forests will continue to decline, due to overexploitation and illegal logging activities. The unlawfully extracted timber and other wood products are mainly exported to developed countries. Thus, robust inspections of the species and origins of internationally traded timber and other wood products might provide authoritative deterrents for illegal logging activities. Indeed, it has been shown that identification of the species that wood products originate from can dramatically reduce the frequencies of false declarations by their importers in Japan (Itoh et al. 2004). The most reliable and convenient tools for identifying the species and geographic origins of such products are likely to be molecular techniques that can be used in conjunction with a DNA database of appropriate marker sequences.

The botanical family Dipterocarpaceae is a key family, both ecologically and commercially, in the forests of Southeast Asia. Members of the family are predominantly distributed in tropical lowland and hill forests within this region, where they accounted for nearly 55\% of the stand volume in lowland forests, according to figures presented by Symington (1943). The family consists of 10 genera with 386 species and shows a high rate of endemicity, which means that more than half of the species are distributed in very restricted regions (Ashton 1982). Shorea is the largest genus in the family, consisting of 192 species (163 of which can be found in Malesia, Ashton 1982). Among these, 108 species are distributed in restricted areas of Southeast Asia. In Peninsular Malaysia, over $57 \%$ of the dipterocarp species have distribution patterns restricted to specific zones within the Peninsula and 124 out of the 157 dipterocarp species of Peninsular Malaysia were listed in some category of threat (Saw and Sam 2000). For species with such a restricted distribution, we can obviously identify the area from which material originates, and the threatened species should be conserved not only for genetic resources but also ecosystem of tropical forests. In Sarawak, there are also strictly protected plant species including eight Shorea species by law (http://www. forestry.sarawak.gov.my/forweb/ourfor/flora/pp/pp.htm).

The genus Shorea has been divided into four sections (Shorea, Rubroshorea, Richetioides and Anthoshorea), which closely follow the four color-based types of timber designated for commercial purposes: Balau, Red Meranti, Yellow Meranti and White Meranti, respectively (Symington 1943). Ashton (1982) divided the genus into ten sections: the sections Shorea, Pentacme, and Neohopea form the timber group of color type Balau, the section Richetioides is the timber group Yellow Meranti, the section Anthoshorea is the timber group White, and the sections Rubella, Brachypterae, Pachycarpae, Mutica and Ovalis are the timber group Red color type. In Japan, the amount of tax paid to import wood derived from Shorea trees depends on which of these groups it is assigned to; the highest tax is for Red Meranti timber (Itoh et al. 2004). For this reason, importers sometimes make false declarations to reduce their tax bills. Tax rates are even lower for a few species that taxonomically belong to Red Meranti, such as Shorea albida and S. rugosa var. uliginosa, probably because of miss-classification for tax.

Timber trees have been utilized by local communities for millennia. However, since commercial logging started, the extent of tropical forests has declined dramatically. Illegal logging activities have contributed to this decline in many regions. The extracted wood is processed to make products, such as sawn timber, veneer and plywood, which are then exported to other countries. Once the timber has been processed, it is generally difficult to identify the species used to make the products, using current techniques. There are exceptions for a few species that yield wood with readily identifiable features. Anatomical analysis of Shorea wood provides sufficient information to classify it to respective timber groups. However, such analysis cannot identify wood to the species level and requires several working days by well-trained and experienced personnel (Desch 1941; Ogata et al. 2008). In such cases, DNA analysis may provide much more powerful and convenient means for identifying the species. Attempts have been made to isolate DNA from woody products of various species, including several oak species, to identify the origin of the wood (Deguilloux et al. 2004). Chloroplast DNA (cpDNA) is frequently used for these analyses, because (1) it is much easier to amplify cpDNA than nuclear DNA, due to the higher copy numbers of chloroplast genomes per cell (Régis and Lerbs-Mache 2001), and (2) a number of cpDNA regions are known to have 
sufficient nucleotide polymorphism to investigate the phylogenetic relationship between species (Soltis and Soltis 1998). Therefore, if robust methods for extracting and analyzing DNA from imported wood products, such as veneers and sawn woods, can be developed, they should be capable of identifying their origins (species and possibly geographic region). This could be very useful for checking the legality of wood products, and for deterring trade in illegal products. The phylogeny of the Dipterocarpaceae has been assessed using several kinds of molecular methods, such as PCR-RFLP analysis of chloroplast genes (Tsumura et al. 1996; Indrioko et al. 2006), and analyses of sequences of cpDNA regions (Kajita et al. 1998; Kamiya et al. 1998; Dayanandan et al. 1999), internal transcribed spacer (ITS) regions (Yulita et al. 2005), and AFLPs (Cao et al. 2006). However, there is still insufficient information for robust molecular classification, and further sequence data are required, covering a greater range of species.

In this study we aimed: (1) to construct a cpDNA sequence database for the genus Shorea, which is the largest genus of the family Dipterocarpaceae and widely distributed within Southeast Asia, and (2) to develop methods for extracting and analyzing DNA from wood samples made from dipterocarp species, in order to check the legality of internationally traded wood and wood products. In addition to describing these efforts, we discuss the feasibility of applying the species identification procedure to wood products in practice, and its limitations.

\section{Materials and methods}

\section{Materials for molecular classification of Shorea}

We collected leaf tissue samples of Shorea species from the arboretums of the Forest Research Institute, Malaysia, the Forest Research Centre, Sabah, and permanent ecological research plots in various locations, such as the Lambir and Pasoh forest reserves in Malaysia. We also collected samples directly from natural forests in Indonesia (for recording purposes, we also deposited herbarium specimens for each collected sample at the Georg-August University of Göttingen). In total, 200 individuals were sampled, representing 84 Shorea species (Supplement Table 1), which covered ca. $70 \%$ of the major commercial timber species in Indonesia and Malaysia (Soerianegara and Lemmens 1994). We also included four numbers of Hopea species and one species of Neobalanocarpus in this study, because the two genera were found to be taxonomically nested in Shorea in a previous study (Tsumura et al. 1996) and it is important to understand the phylogenetic positions of these two genera within Shorea.
DNA extraction and sequencing of intergenic spacer regions of cpDNA

Total DNA was extracted using the modified CTAB method (Tsumura et al. 1996), or a DNeasy Plant Mini Kit (Qiagen). Four non-coding regions of the chloroplast genome were selected for polymerase chain reaction (PCR) amplification, based on the high degrees of polymorphism found in preliminary studies: $\operatorname{trn} \mathrm{L}$ (UAA) intron, $t r n \mathrm{~L}$ (UAA) $3^{\prime}$ exon and $\operatorname{trn} \mathrm{F}$ (GAA), $\operatorname{trn} \mathrm{H}(\mathrm{GUG})$ and trnK(UUU), and $p s b \mathrm{C}$ and $t r n \mathrm{~S}(\mathrm{UGA})$ (Table 1).

The PCR reaction mixtures contained PCR buffer (10 mM Tris- $\mathrm{HCl}, 50 \mathrm{mM} \mathrm{KCl,} 100 \mu \mathrm{M}$ of each dNTP, $0.02 \%$ Triton X-100 and $0.01 \%$ gelatin), $1.5 \mathrm{mM} \mathrm{MgCl}_{2}$, $0.4 \mathrm{U}$ Taq DNA polymerase (Promega), $0.2 \mu \mathrm{M}$ of each primer, and $10 \mathrm{ng}$ template DNA in a total volume of $20 \mu \mathrm{l}$. The PCR conditions consisted of an initial $3 \mathrm{~min}$ denaturation at $94^{\circ} \mathrm{C}$ then 30 cycles of $30 \mathrm{~s}$ denaturation at $94^{\circ} \mathrm{C}, 45 \mathrm{~s}$ annealing at $56^{\circ} \mathrm{C}$, and $45 \mathrm{~s}$ extension at $72^{\circ} \mathrm{C}$, with a final 5 min extension at $72^{\circ} \mathrm{C}$.

The PCR products were purified using a QIAquick PCR purification kit (Qiagen). Purified PCR products were used as templates for cycle sequencing reactions using a BigDye Terminator Cycle Sequencing Ready Reaction kit (Applied Biosystems) and DNA sequencing was performed with an ABI PRISM 3100 Genetic Analyzer (Applied Biosystems). All four selected regions were sequenced in both directions for all individuals, and the obtained sequences were aligned manually and/or using CLUSTAL_W software (Thompson et al. 1997).

\section{Analysis of chloroplast sequence data}

We constructed a molecular phylogenetic tree using the neighbor-joining method (Saitou and Nei 1987) to test for clustering according to wood groups, which are defined according to color-Red Meranti, Yellow Meranti, White Meranti and Balau (Symington 1943)_and are monophyletic. The robustness of the resulting phylogenetic tree was tested by bootstrap analysis (Felsenstein 1985) with 1000 replicates using MEGA4 software (Tamura et al. 2007). The species Vatica bella, V. oblongifolia, Anisoptera laevis and Cotylelobium lanceolatum were used as an outgroup for the evaluation. In expectation that each wood color group would prove to be monophyletic, nucleotide substitutions that could be used to discriminate the four groups were sought, using the sequence alignment data. We also searched for nucleotide substitutions capable of discriminating between species within groups, especially for Shorea albida, since the tax rate applied to wood of this species is different from the rate applied to other Shorea species in Japan. 
Table 1 Analyzed regions of chloroplast DNA and their sequence primers

\begin{tabular}{|c|c|c|c|c|}
\hline Region & Names of primers & Sequences $\left(5^{\prime} \rightarrow 3^{\prime}\right)$ & & Length $(b p)^{\mathrm{a}}$ \\
\hline \multirow[t]{2}{*}{$\operatorname{trnL}(\mathrm{UAA})$ intron } & $\mathrm{cp} 2 \mathrm{~F}$ & CGAAATCGGTAGACGCTACG & Taberlet et al. (1991) & 506 \\
\hline & $\mathrm{cp} 2 \mathrm{R}$ & GGGGATAGAGGGACTTGAAC & Taberlet et al. (1991) & \\
\hline \multirow[t]{2}{*}{ 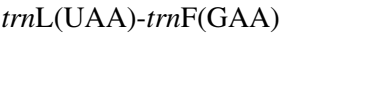 } & $\mathrm{cp} 3 \mathrm{~F}$ & GGTTCAAGTCCСТCTATCCC & Taberlet et al. (1991) & 441 \\
\hline & $\mathrm{cp} 3 \mathrm{R}$ & ATTTGAACTGGTGACACGAG & Taberlet et al. (1991) & \\
\hline \multirow[t]{7}{*}{ 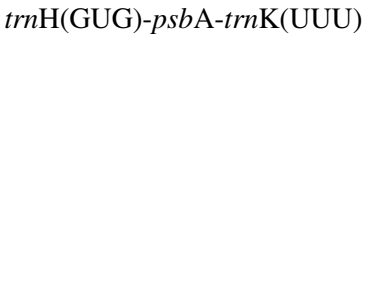 } & $\mathrm{cp} 5 \mathrm{~F}$ & ACGGGAATTGAACCCGCGCA & Demesure et al. (1995) & 1780 \\
\hline & cp5R & CCGACTAGTTCCGGGTTCGA & Demesure et al. (1995) & \\
\hline & cp5iF1 & TTTTCTGTGGTTTCCCTGAT & & \\
\hline & cp5iF2 & GCRATGAAGGCRATAATAAA & & \\
\hline & cp5iR1 & TGCTCAYAACTTCССТСТА & & \\
\hline & cp5iR2 & TCCCTATTCAGTGCTATGC & & \\
\hline & cp5iR3 & CCGCAACTTCTGTATTTATT & & \\
\hline \multirow[t]{6}{*}{$p s b \mathrm{C}-\operatorname{trn} \mathrm{S}(\mathrm{UGA})$} & cp6F & GGTCGTGACCAAGAAACCAC & Demesure et al.(1995) & 1559 \\
\hline & cp6R & GGTTCGAATCCCTCTCTCTC & Demesure et al.(1995) & \\
\hline & cp6iF1 & TGGAGGAGAAGGATGGATTG & & \\
\hline & cp6iF2 & GCCACCTCTCATTTTGTTCT & & \\
\hline & cp6iR1 & ACАСТСАСААТССАТССТТС & & \\
\hline & cp6iR2 & CCCAGAACAAAATGAGAGGT & & \\
\hline \multicolumn{5}{|c|}{ Primers for amplification of small fragment for plywood } \\
\hline \multirow[t]{6}{*}{ 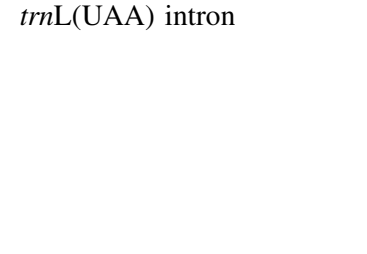 } & $2 \mathrm{AF}$ & CGAAATCGGTAGACGCTACG & & \\
\hline & $2 \mathrm{AR}$ & GAATAGGTGTCCCAGTCGTT & & 306 \\
\hline & $2 \mathrm{BF}$ & ACTGGGACACCTATTCTT & & \\
\hline & $2 \mathrm{BR}$ & CTATCTTTATTCTCGTCCAA & & 190 \\
\hline & $2 \mathrm{CF}$ & AATGGATTAATTGGACGAGAA & & \\
\hline & $2 \mathrm{CR}$ & GGGGATAGAGGGACTTGAAC & & 129 \\
\hline
\end{tabular}

${ }^{a}$ Lengths include alignment gaps

Species identification of dipterocarp wood products using anatomical characteristics

Four veneer samples imported from Sabah, Malaysia, were obtained from the Maruhi Plywood Co., Tokyo, Japan, four other veneer samples from Key Tec Co. Ltd, Tokyo, Japan, and two sawn timber samples were also used in this study. In order to identify the wood species of the veneers by light microscopy, thin sections were cut from transverse, radial and tangential surfaces of each sample using razor blades. Each section was then mounted in a drop of glycerol on a glass slide and covered with a cover slip. The glass slides were heated on a hot plate for several minutes at 120$150^{\circ} \mathrm{C}$ to remove bubbles in the sections. After the samples had cooled down, the sections were observed under a light microscope. Common anatomical feature of genus Shorea is the existence of axial resin canals which arrange concentrically. Anatomical characteristics of wood groups are (1) Balau; thick fiber wall and crystal in chambered axial parenchyma, (2) Red Meranti; red color in wood and crystals in idioblasts, (3) Yellow Meranti; yellow color in wood and the existence of radial resin canals in rays, and
(4) White Meranti; silica grains deposited in rays. The other special characteristics, radial resin canals with extremely large diameter are existed in three species such as S. leprosula, S. ovata, and S. teysmaniana of Red Meranti. To observe the woody characters in greater detail, we also used a scanning electron microscope. For this purpose, the samples were treated with aqueous sodium hypochlorite for $3 \mathrm{~min}$ to remove residual cell contents from the surfaces of vessel walls, rinsed copiously with water, then dehydrated with $99 \%$ ethanol, and finally dried in air. The samples were observed under a scanning electron microscope with or without metal coating. The structures of the xylem vessel walls were then classified.

Extraction and analysis of DNA from dipterocarp wood products

The ten veneer and timber samples were cut into smaller pieces with a pair of pruning scissors, and ca. $1 \mathrm{~g}$ samples were powdered with a disruptor (Multi-Beads shocker; Yasui Kikai Co., Japan). DNA was extracted using the DNeasy Plant Mini Kit and a QIAshredder Maxi Spin 
Column from the DNeasy Plant Maxi Kit (Qiagen). DNA concentration was determined using a fluorescence spectrophotometer (F-3010; Hitachi) with $\lambda$ DNA as a standard. Four cpDNA regions were amplified by PCR (Table 1). The PCR reaction mixtures consisted of $12.5 \mu 1$ of $2 \times$ Ampdirect Plus (Shimadzu), $0.25 \mu \mathrm{l}$ (0.625 unit) of Blend Taq-Plus (Toyobo), $0.5 \mu \mathrm{M}$ primers and $5 \mu \mathrm{l}$ of template DNA in a total volume of $25 \mu \mathrm{l}$. Amplification was performed with an initial denaturation step at $94^{\circ} \mathrm{C}$ for $90 \mathrm{~s}$ followed by 40 cycles of denaturation at $94^{\circ} \mathrm{C}$ for $30 \mathrm{~s}$, annealing at $56^{\circ} \mathrm{C}$ for $30 \mathrm{~s}$, and extension at $72^{\circ} \mathrm{C}$ for $50 \mathrm{~s}$. PCR products were purified using a Wizard SV Gel and PCR Clean-Up System (Promega) according to the manufacturer's instructions. Sequences were determined in both directions by direct sequencing with the same primers that were used in the PCR.

An attempt was also made to extract and analyze DNA, to species level, from a plywood sample originating from an unknown dipterocarp species. Plywood is made by a process involving heating wood veneers and joining them with adhesives, most likely resulting in strong degradation of the DNA. We peeled away the surface of the plywood and powdered ca. $200 \mathrm{mg}$ of the wood in liquid nitrogen using a mortar and pestle. The DNeasy Plant Mini Kit was used for DNA extraction, applying a modification in which fourfold more buffer was used for all steps and the incubation time at $65^{\circ} \mathrm{C}$ was increased to $120 \mathrm{~min}$. PCR amplification was done using a Qiagen Multiplex PCR kit according to the manufacturer's protocol. We amplified the four cpDNA regions used for the molecular classification of Shorea and three small fragments of the trnL using newly designed primers (Table 2), since we expected the DNA to be highly degraded. The sequencing and sequence alignment procedures were the same as those described above for the molecular classification of Shorea.

\section{Results}

\section{Molecular classification of Shorea}

We aligned sequences obtained from each of the samples for the following regions: $\operatorname{trn} \mathrm{L}$ intron $(506 \mathrm{bp}), \operatorname{trn} \mathrm{L}-\operatorname{trn} \mathrm{F}$ (441 bp), trnH-trnK (1780 bp), and psbC-trnS (1559 bp). Sequences obtained were deposited in the DNA Data Bank of Japan database, DDBJ (accession numbers AB451979AB452810, AB458531-AB458538). The total sequence length was $4286 \mathrm{bp}$, including some gaps. The numbers of polymorphic sites that could be used to classify the species into wood groups ranged from 17 for Yellow Meranti to 128 for Red Meranti, and the number of informative sites of the four cpDNA regions increased with sequence length (Table 2). Within-group nucleotide diversity was highest for the White Meranti and lowest for the Yellow Meranti group (Table 3). Among the four cpDNA regions, the trnL$\operatorname{trn} \mathrm{F}$ region had the highest nucleotide diversity, two- to threefold higher than each of the other three examined regions.

The phylogenetic tree suggested that each group based on wood color is monophyletic (Fig. 1a), except for S. roxburghii (Fig. 1c), implying that we should be able to find nucleotide substitutions capable of distinguishing each of the four groups. Numbers of unique difference nucleotide sites detected in the White, Yellow, Balau and Red Meranti groups amounted to 9, 116 and 5, respectively (Table 4). These nucleotide substitutions provide diagnostic DNA

Table 2 Polymorphic sites (singleton and parsimony-informative sites) used to classify the species within wood groups

\begin{tabular}{|c|c|c|c|c|c|}
\hline Group & $\begin{array}{l}\operatorname{trn} \mathrm{L} \\
506 \mathrm{bp}\end{array}$ & $\begin{array}{l}\text { trnL-trnF } \\
441 \mathrm{bp}\end{array}$ & 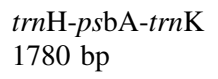 & $\begin{array}{l}p s b \mathrm{C}-t r n \mathrm{~S} \\
1559 \mathrm{bp}\end{array}$ & Total \\
\hline White Meranti & $11(4,7)$ & $14(0,14)$ & $42(7,35)$ & $39(4,35)$ & $106(15,91)$ \\
\hline Yellow Meranti & $3(2,1)$ & $4(1,3)$ & $5(3,2)$ & $5(4,1)$ & $17(10,7)$ \\
\hline Balau & $7(2,5)$ & $18(6.12)$ & $35(24,11)$ & $41(12,29)$ & $101(44,57)$ \\
\hline Red Meranti & $11(7,4)$ & $26(9,17)$ & $48(27,21)$ & $43(30,13)$ & $128(73,55)$ \\
\hline
\end{tabular}

Table 3 Nucleotide diversity of four chloroplast DNA regions in the four wood groups

\begin{tabular}{lllll}
\hline Group & trnL (SD) & trnL-trnF (SD) & trnH-psbA-trnK (SD) & $p s b C-t r n S(\mathrm{SD})$ \\
\hline White Meranti & $0.00468(0.00098)$ & $0.01043(0.00194)$ & $0.00679(0.00148)$ & $0.00555(0.00161)$ \\
Yellow Meranti & $0.00075(0.00030)$ & $0.00164(0.00039)$ & $0.00060(0.00013)$ & $0.00037(0.00022)$ \\
Balau & $0.00176(0.00050)$ & $0.00674(0.00097)$ & $0.00282(0.00050)$ & $0.00418(0.00048)$ \\
Red Meranti & $0.00149(0.00019)$ & $0.00515(0.00052)$ & $0.00142(0.00024)$ & $0.00129(0.00027)$ \\
\hline
\end{tabular}


(a) Overview

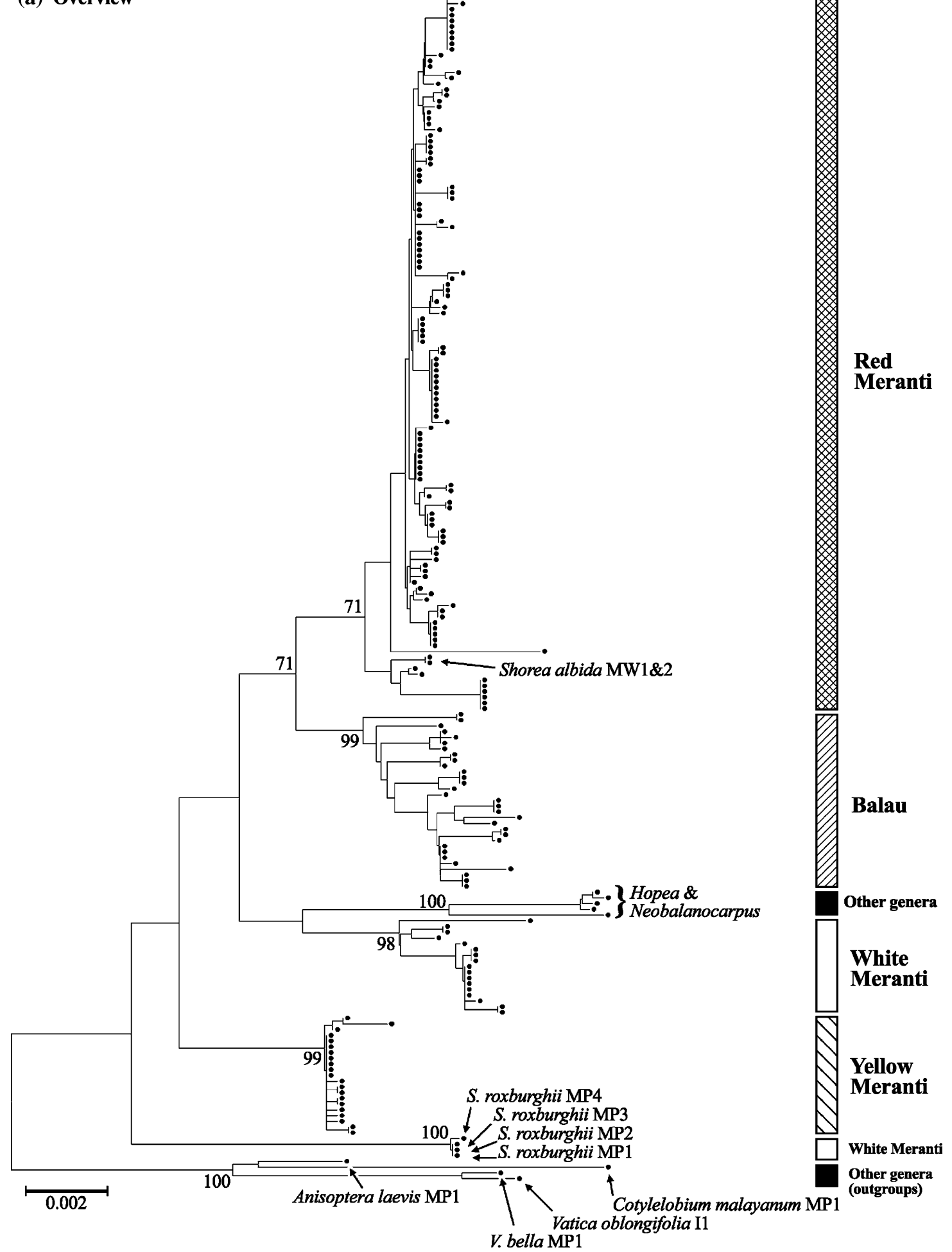

Fig. 1 Phylogenetic tree of Shorea species based on sequence data obtained for four chloroplast DNA regions: a overview of the phylogeny, b Red Meranti group, c Balau, d White Meranti, e Yellow Meranti groups. The letters in parentheses indicate origins of the species (MP Peninsular Malaysia, $M W$ Sarawak Malaysia, MS Sabah
Malaysia, I Indonesia) and the following numbers indicate numbers assigned to individuals when we analyzed multiple individuals of each species from the same geographic region. Numbers above and below branches indicate percentages of 1,000 bootstrap replications exceeding $50 \%$ 


\section{(b) Red Meranti}

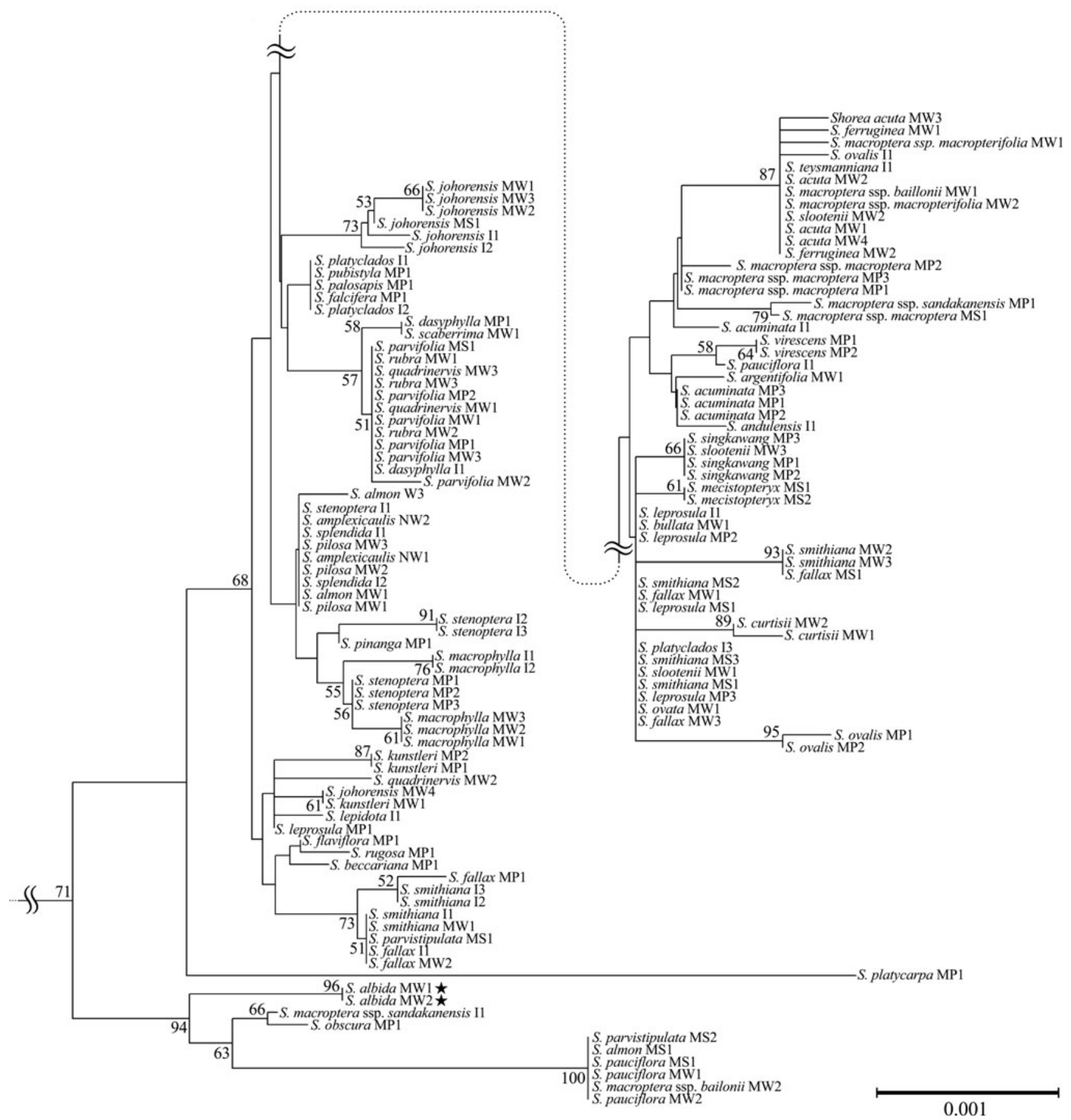

Fig. 1 continued

markers for the four groups. The bootstrap values of the nodes for the White, Yellow, Balau and Red groups were 97, 99, 95 and 65, respectively (Fig. 1a).

Sixteen combinations of species have identical sequences in the four examined cpDNA regions (Table 5) and the total number of combinations having identical sequence was 124 , of which 67 combinations was identical within species of different individuals and 57 combinations was identical between species because we analyzed multiple individuals for each species. For example, the sequences of the four regions were found to be identical in S. pilosa, S. splendida, and S. amplexicaulis, all of which belong to the same section of Shorea (Pachycarpae). The probability of two species having an identical sequence between 
(c) Balau

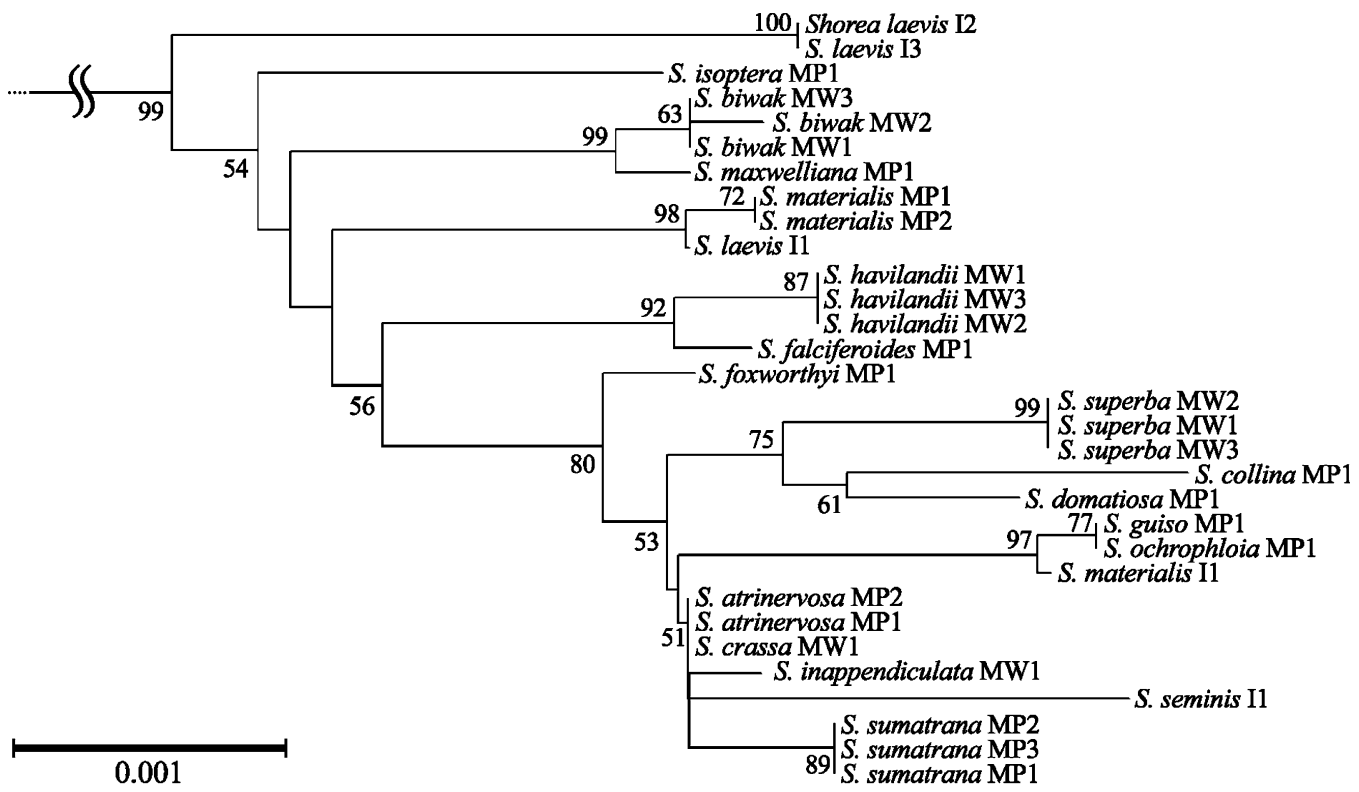

(d) White Meranti \& other genera

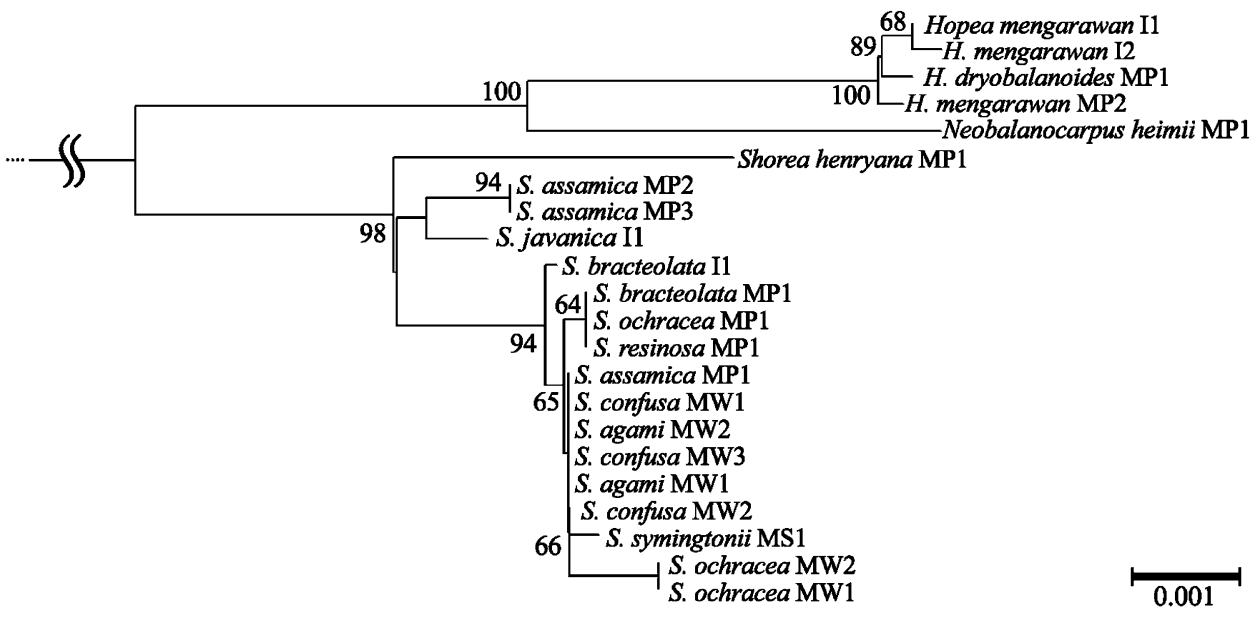

(e) Yellow Meranti

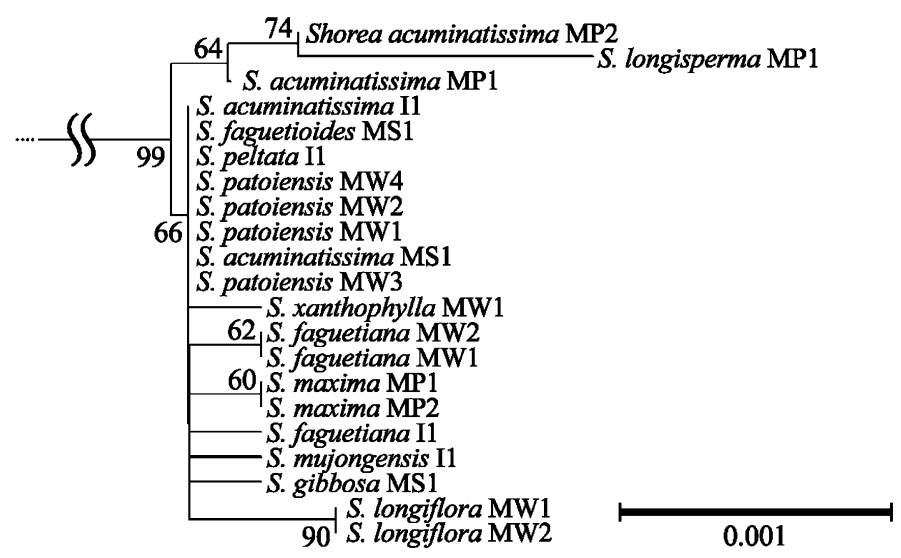

Fig. 1 continued 
Table 4 Discriminated nucleotide substitutions between the four wood groups (indicated by bold type)

\begin{tabular}{|c|c|c|c|c|c|c|c|c|c|c|c|c|c|c|c|c|c|c|}
\hline \multirow[t]{2}{*}{ Group } & \multicolumn{5}{|c|}{$\operatorname{trn} \mathrm{L}(\mathrm{bp})$} & \multicolumn{7}{|c|}{$\operatorname{trn} \mathrm{L}-\operatorname{trn} \mathrm{F}(\mathrm{bp})$} & \multicolumn{6}{|c|}{$t r n \mathrm{H}-p s b \mathrm{~A}-t r n \mathrm{~K}(\mathrm{bp})$} \\
\hline & 190 & 214 & 285 & 296 & 358 & 17 & 52 & 203 & 220 & 245 & 269 & 300 & 92 & 637 & 1,416 & 1,509 & 1,532 & 1,681 \\
\hline White Meranti & $\mathrm{C}$ & $\mathrm{T}$ & $\mathbf{T}$ & $\mathrm{T}$ & $\mathrm{T}$ & $\mathrm{G}$ & $\mathrm{C}$ & $\mathbf{A}$ & $\mathrm{C}$ & $\mathrm{T}$ & $\mathrm{C}$ & $\mathbf{C}$ & $\mathbf{C}$ & $\mathbf{A}$ & $\mathrm{C}$ & G & $\mathrm{C}$ & $\mathrm{T}$ \\
\hline Yellow Meranti & $\mathbf{T}$ & $\mathbf{G}$ & $\mathrm{C}$ & $\mathbf{G}$ & $\mathrm{T}$ & $\mathrm{G}$ & $\mathrm{C}$ & G & $\mathbf{T}$ & $\mathbf{G}$ & $\mathbf{G}$ & $\mathrm{T}$ & $\mathrm{T}$ & $\mathrm{G}$ & $\mathbf{A}$ & $\mathrm{G}$ & $\mathbf{A}$ & $\mathrm{T}$ \\
\hline Balau & $\mathrm{C}$ & $\mathrm{T}$ & $\mathrm{C}$ & $\mathrm{T}$ & $\mathbf{A}$ & G & $\mathbf{T}$ & G & $\mathrm{C}$ & $\mathrm{T}$ & $\mathrm{C}$ & $\mathrm{T}$ & $\mathrm{T}$ & $\mathrm{G}$ & $\mathrm{C}$ & $\mathbf{T}$ & $\mathrm{C}$ & $\mathrm{T}$ \\
\hline Red Meranti & $\mathrm{C}$ & $\mathrm{T}$ & $\mathrm{C}$ & $\mathrm{T}$ & $\mathrm{T}$ & $\mathbf{A}$ & $\mathrm{C}$ & $\mathrm{G}$ & $\mathrm{C}$ & $\mathrm{T}$ & $\mathrm{C}$ & $\mathrm{T}$ & $\mathrm{T}$ & G & $\mathrm{C}$ & G & $\mathrm{C}$ & $\mathbf{C}$ \\
\hline \multirow[t]{2}{*}{ Group } & \multicolumn{16}{|c|}{$p s b \mathrm{C}-t r n \mathrm{~S}(\mathrm{bp})$} & & \\
\hline & 74 & 109 & 484 & 526 & 637 & 655 & 70 & & 766 & 1,139 & 1,378 & 1,39 & & 1,414 & 1,445 & 1553 & & \\
\hline White Meranti & $\mathrm{C}$ & $\mathrm{C}$ & $\mathrm{C}$ & $\mathbf{G}$ & $\mathrm{T}$ & G & $\mathbf{C}$ & & $\mathrm{T}$ & A & $\mathbf{A}$ & $\mathrm{T}$ & & A & $\mathrm{C}$ & $\mathrm{G}$ & & \\
\hline Yellow Meranti & $\mathbf{T}$ & $\mathrm{C}$ & $\mathrm{C}$ & A & $\mathrm{T}$ & $\mathrm{T}$ & $\mathrm{T}$ & & $\mathrm{T}$ & A & $\mathrm{T}$ & $\mathrm{T}$ & & A & $\mathbf{T}$ & A & & \\
\hline Balau & $\mathrm{C}$ & $\mathrm{C}$ & $\mathrm{T}$ & A & $\mathbf{C}$ & $\mathrm{T}$ & $\mathrm{T}$ & & $\mathbf{C}$ & A & $\mathrm{T}$ & $\mathrm{T}$ & & $\mathbf{G}$ & $\mathrm{C}$ & $\mathrm{G}$ & & \\
\hline Red Meranti & $\mathrm{C}$ & $\mathbf{T}$ & $\mathrm{T}$ & A & $\mathrm{T}$ & $\mathrm{T}$ & $\mathrm{T}$ & & $\mathrm{T}$ & $\mathbf{T}$ & $\mathrm{T}$ & C & & A & $\mathrm{C}$ & $\mathrm{G}$ & & \\
\hline
\end{tabular}

Table 5 Shorea species having identical sequence data based on four region of cpDNA

\begin{tabular}{ll}
\hline Species & Species with identical sequence \\
\hline S. agami (MW2), 5 & S. assamica (MP1), 5, S. confusa (MW2), 5, S. confusa (MW1), 5, S. agami (MW1), 5 \\
S. acuta (MW4), 9a & S. macroptera ssp. macropterifolia (MW2), 9b, S. acuta (MW2), 9a, S. acuta (MW1), 9a \\
S. pilosa (MW2), 8 & S. almon (MW1), 7b, S. amplexicaulis (MW1), 8, S. amplexicaulis (MW2),8, S. splendida (I1), 8, \\
& S. splendida (I2), 8, S. pilosa (MW3), 8, S. pilosa (MW1), 8 \\
S. dasyphylla (I1), 9b & S. parvifolia (MP2), 7b, S. parvifolia (MP1), 7b, S. parvifolia (MW3), 7b, S. parvifolia (MW1), 7b \\
S. falcifera (MP1), 1a & S. palosapis (MP1), 7b \\
S. fallax (MS1), 7b & S. smithiana (MW3), 7a \\
S. fallax (MW2), 7b & S. smithiana (MW1), 7a, S. parvistipulata (MS1), 7b \\
S. ferruginea (MW2), 9a & S. slootenii (MW2), 9a, S. macroptera ssp. baillonii (MW1), 9a, S. teysmanniana (I1), 9b \\
S. guiso (MP1), 1a & S. ochrophloia (MP1), 1a \\
S. quadrinervis (MW1), 9b & S. rubra (MW3), 9b, S. rubra (MW1), 9b, S. rubra (MW2), 9b, S. quadrinervis (MW3), 9b
\end{tabular}

Letters in parenthesis indicate the sample number and the following number indicates the section of the species based on Ashton (1982)

1, Section Shorea, 1a, Subsection Shores, 1b, Subsection Barbata, 2, Section Pentacme, 3, Section Neohopea, 4, Section Richetioides, 4a, Subsection Polyandrae, 4b, Subsection Richetioides, 5, Section Anthoshorea, 6, Section Rubella, 7, Section Brachypterae, 7a, Subsection Smithiana, 7b, Subsection Brachypterae, 8, Section Pachycarpae, 9, Section Mutica, 9a, Subsection Auriculatae, 9b, Subsection Mutica, 10, Section Ovalis

different species was only $1.64 \%[57 /((84 \times 83) / 2)]$, thus most of species can be identified by our cpDNA data.

We found multiple haplotypes in 28 out of 47 species when analyzing multiple samples (2-10 samples with an average of 3.45) from the same species, but all of the haplotypes within a species were very similar to each other (Fig. 1b, c). Some species that shared haplotypes with other species (Table 5), as described above, appeared to have more complex relationships with other species, especially in the Red Meranti group (Fig. 1b). However, species from different wood varieties did not share chloroplast haplotypes. The Hopea and Neobalanocarpus group was found to be a sister of the White Meranti group (Fig. 1c). Based on our data, we have developed an online molecular database to identify Shorea and closely related species in Dipterocarpaceae using FASTA software (http://f5002.ffpri-108.affrc.go.jp/shorea/).

\section{Discrimination of S. albida}

We analyzed two individuals that were collected in different forests, but their sequences of the four examined regions of cpDNA were identical. We found two unique nucleotide sites in S. albida that were not present in any of the other Shorea species examined. These were the 11th and 1225th sites of the trnH-psbA-trnK sequence, at which $\mathrm{G}$ and C, respectively, were present in S. albida, while A and G were present in all of the other Shorea species. 
Species identification of woody products by anatomical observations

Eight veneer samples and one sawn timber sample were identified as wood of species from the sections Brachypterae, Pachycarpae, Mutica, and Ovalis (Red Meranti), based on the wood's anatomical features (Desch 1941; Ogata et al. 2008). The other sawn timber sample (no. 2) was identified as originating from the Yellow Meranti group, because of the presence of small radial resin canals. Veneer 1 had crystals in idioblasts in its axial and ray parenchyma tissue, diffuse-porous wood with warts on its vessel wall surfaces and thin-walled fibers (Table 6). Therefore, candidate species include: S. fallax, S. parvistipulata, S. macrophylla, S. almon, S. johorensis, S. palembanica and S. ovalis (see details in Desch 1941; Ogata et al. 2008). Veneer samples 2, 3, 4, 6, 7 and 8 shared a number of anatomical features, notably crystals in idioblasts in axial parenchyma (but not in rays), warts present on vessel walls, and thin fiber walls. Therefore, candidate species for these samples were $S$. parvifolia, S. smithiana, S. mecistopteryx, S. ovalis, and/or S. rubra (Table 6). Sawn timber $1 \mathrm{had}$ anatomical features of the Red Meranti group including large radial resin canals, which are a typical feature of S. leprosula.

Species identification of woody products using DNA sequence data

DNA was extracted from eight veneer samples collected before the drying step in the manufacturing process. The amount of extracted DNA ranged from 0.4 to $4.2 \mu \mathrm{g}$ per $\mathrm{g}$ fresh weight sample. The four non-coding regions of the chloroplast genome $(t r n \mathrm{~L}$ intron, $\operatorname{trn} \mathrm{L}-t r n \mathrm{~F}, \operatorname{trn} \mathrm{H}-p s b \mathrm{~A}$ and $p s b$-trnS) were successfully amplified from the extracted DNA. The sequences of the PCR products were searched against a database constructed in this study using FASTA software. Shorea species whose sequences completely matched the query sequences across all four regions were regarded as candidate source species of the veneers. For veneer 1, S. fallax and S. johorensis were identified as candidates; only one nucleotide out of ca. $4.2 \mathrm{kbp}$ did not match the query sequence in this case and for the other samples we could also find the candidate species (Table 6).

PCR amplification of the $\operatorname{trn} \mathrm{L}$ intron, $\operatorname{trn} \mathrm{L}-t r n \mathrm{~F}, \operatorname{trn} \mathrm{H}-$ $p s b \mathrm{~A}$ and $p s b \mathrm{C}$-trnS regions of cpDNA from plywood failed, but three small fragments of the $t r n \mathrm{~L}$ intron were successfully amplified. After alignment of the sequence data, we searched against a database constructed in this study using FASTA software, and identified Hopea spp. as a candidate species (Table 6).

\section{Discussion}

Molecular classification and the limitations of using Shorea cpDNA sequences

We have sequenced $4.2 \mathrm{kbp}$ of cpDNA for identifying Shorea species. However, some species belonging to the same sections have identical sequences, as described above, indicating that it may be difficult to discriminate between closely related species within the genus solely using cpDNA sequence data. ITS regions may be much better for classifying species of the genus (Yulita et al. 2005), but their complicated and uninferable evolutionary history may reduce their utility for phylogenetic analysis, for which single-copy nuclear genes are generally more robust (Álvarez and Wendel 2003).

In our dataset we found many nucleotide substitutions between the four woody groups, which provide convenient candidate sites for developing markers to use with techniques such as multiplex allele-specific PCR (Vallone et al. 2004). The woody group with the highest nucleotide diversity was White Meranti (Table 3), partly because one of its members, $S$. roxburghii, has a unique sequence that is close to sequences of Yellow Meranti species (Fig. 1). However, even when we estimated the nucleotide diversity of the White Meranti group excluding the $S$. roxburghii data, we still found it to be more diverse than the other groups (data not shown). We investigated 21, 43, 11 and 15 species, representing 2, 5, 1 and 1 sections of Balau, Red, White and Yellow Meranti (Ashton 1982), respectively. The classification based on morphological data is not entirely consistent with the variations in their chloroplast sequences, probably because cpDNA evolves more slowly than nuclear DNA, which contains genes that are strongly associated with most morphological and physiological characters. This inconsistency is prominent in the species of Red Meranti, the largest group in Shorea. For more detailed molecular classification of Red Meranti species, it will be necessary to obtain nuclear sequence information in further studies. However, S. albida, which belongs to Red Meranti taxonomically (section Rubella, Ashton 1982) and its wood is subjected to different tax rates from other members of Red Meranti in Japan, was clearly discriminated by cpDNA sequence data. Therefore, these nucleotide variations should be useful for discriminating $S$. albida from other Red Meranti species to detect illegal trading. Chloroplast sequence data can also be used to discriminate the compact sections of Shorea, such as the sections Rubella, Neohopea, Ovalis and also section Shorea subsection Shorea. The rate of sharing identical sequences was only $57(1.64 \%)$ between species among 3486 combinations of species, which is quite low. Therefore, our cpDNA 


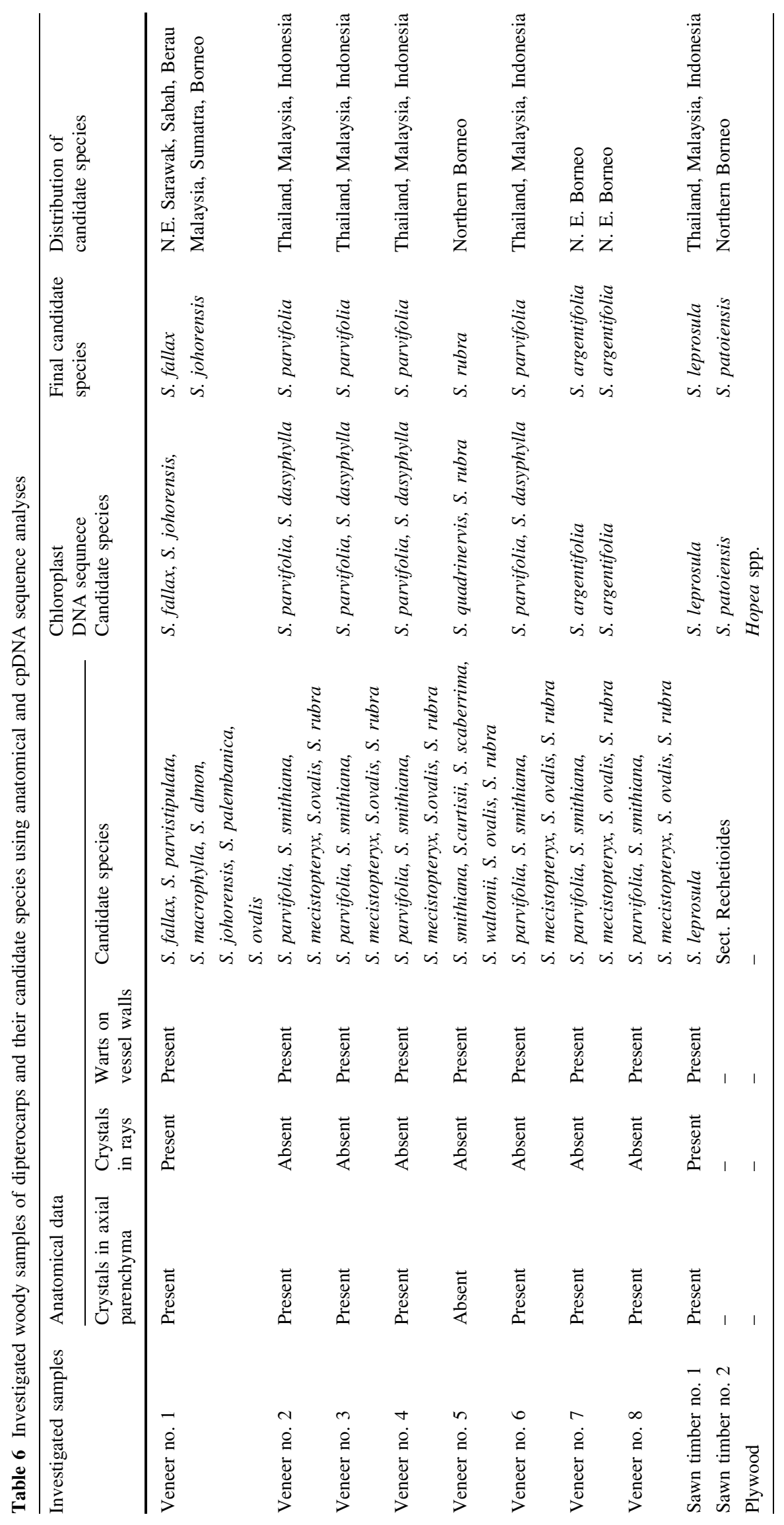


database can be used robustly to identify Shorea species in most cases.

Kamiya et al. (1998) reported that the Yellow Meranti group, White Meranti group and Selengan Batu (Balau) were each monophyletic, but they concluded that the Red Meranti group was paraphyletic. However, all four woody groups seem to be monophyletic except for S. roxburghii according to our results, with bootstrap value for the divergence of Yellow, White, Balau and Red of 99, 98, 99 and $71 \%$, respectively (Fig. 1a). Kamiya et al. (1998) used two regions of cpDNA of less than $900 \mathrm{bp}$ to construct their phylogenetic tree of dipterocarps, but our length was approximately $4200 \mathrm{bp}$. The limited $900 \mathrm{bp}$ dataset may explain why the cited authors concluded that the Red Meranti group was paraphyletic. Our larger dataset also confirms that the Hopea and Neobalanocarpus group is closest to the White Meranti group, which was also previously showed by Kamiya et al. (1998, 2005).

Some species belonging to different sections have identical sequences in the four examined cpDNA regions (Table 5), possibly because of hybridization or recent divergence of species from shared origins. In some cases at least, since cpDNA is generally maternally inherited, hybridization may result in such patterns. In accordance with this hypothesis, hybrid dipterocarps are sometimes found in natural forests. For instance, interspecific hybrids between S. curtisii and S. leprosula have been reported from Peninsular Malaysia and Singapore (Ashton 1982). Kamiya et al. (2005) also suggested that Neobalanocarpus originated from hybridization between members of the White Meranti in Shorea and Hopea. In addition, Ishiyama et al. (2003) found that part of nuclear GapC sequence in one species resembling that in another species of four Shorea species, probably resulting from recombination between two divergent haplotypes. To distinguish between species (and test the hybridization hypotheses), it will be necessary to acquire more data on nuclear DNA sequences, as well as their cpDNA sequences, because if a species has hybrid origins its cpDNA will be derived from the maternal species but its nuclear DNA will be derived from both parental species and thus need to use single-copy nuclear genes as mentioned above. However, for assessing the origins of woody samples and/or small samples, the chloroplast genome is still the best choice for analysis, because of its high copy number per cell (Régis and Lerbs-Mache 2001), robustness, and polymorphism.

In this study, we examined multiple samples of each species collected from individuals in various regions, including Peninsular Malaysia, Sabah, Sarawak and Indonesia. The sequences found in some individuals were not identical to those found in some of their conspecifics, indicating that it may be possible to identify the geographic regions from which individuals of some species originated.
However, in some cases, closely related species shared the same haplotypes, especially some Red Meranti members, possibly reflecting hybridization events or recent divergence of species from shared origins. To confirm these possibilities and to distinguish between samples of different species and geographic origins with confidence, we must investigate more samples originating from many regions and accumulate more data.

Our molecular database covers ca. $70 \%$ of major timber species in the genus Shorea in Indonesia and Malaysia (Soerianegara and Lemmens 1994). It might not be easy to collect samples of all species of Shorea, because some species are very rare. However, it is necessary to increase the proportion of species covered in these areas for more accurate identification of the species.

Species identification of woody products

Morphological features, such as wood color, the presence of axial resin canals, vestured pits, silica grains, and crystals in tissue of Shorea species, provide information that can be used for identification to the wood group level (Desch 1941; Ogata et al. 2008). In this study, we were able to narrow down the investigated woods to several candidate species using anatomical methods. However, candidate species of veneer samples 7 and 8 by anatomical analysis were incongruent with those by cpDNA sequence (Table 6). This is probably because the anatomical database was constructed by the limited number of analyzed samples for each species and thus the false identification may sometimes be occurred. Although such analysis requires several working days by well-trained and experienced personnel, the information generated can help to deter false declarations regarding imported timber and, hence, reduce the trade of illegal timber. However, in order to protect the genetic resources of Shorea species in Southeast Asia, identification at the species level is more important, because nearly half of the species have very restricted distributions and many of them are threatened (Ashton 1982; Saw and Sam 2000). In such cases, we may identify the region the wood sample has originated from. The final candidate species of veneer samples $1,5,7,8$ and sawn timber sample 2 have relatively restricted distribution areas, so we know the area where the timber came from (Table 6). If the identified species distributed only in conservation areas or was protected species such as endangered species (Saw and Sam 2000, http://www.forestry.sarawak.gov.my/ forweb/ourfor/flora/pp/pp.htm), we can know that the timber was collected illegally. However, the other five samples are widespread species and thus it is necessary to study the phylogeography within species to identify their origins. 
Extracting DNA from a plywood sample proved to be difficult, and we did not obtain sufficient DNA to visualize molecules on agarose gels. PCR amplification of the four regions (506, 441, 1780 and $1559 \mathrm{bp}$ ) of cpDNA also failed, probably due to physical degradation of the DNA during the plywood manufacturing process. These results are in accordance with previous reports that it is sometimes difficult to extract DNA from woody products or old wood samples (Deguilloux et al. 2002; Tani et al. 2003; Takahashi et al. 2008), although short DNA fragments probably still remain within the wood. Such small DNA fragments of multiple-copy genomes such as cpDNA can be amplified by PCR (Deguilloux et al. 2002; Parducci et al. 2005; Liepelt et al. 2006; Rachmayanti et al. 2009), and in this study we successfully amplified three small fragments of the $\operatorname{trn} \mathrm{L}$ intron region, ranging in size from 129 to $306 \mathrm{bp}$. These results indicate that even if the DNA in a sample has been seriously degraded, as in the plywood samples, it may still be possible to amplify small fragments $(<300$ bp) by PCR. In the Shorea molecular classification database, we accumulated cpDNA sequence data for most of the major Shorea species in Southeast Asia. Using such information, it should be possible to design species-specific PCR primers to amplify short fragments of target species, including discriminating nucleotide substitutions from other species when necessary, and use them to identify source species of recalcitrant woody products such as plywood. In this time we have tried to analyze only one sample from plywood and could obtain the result. However, the developed method for analyzing DNA from especially plywood is not still perfect and probably need to improve it more because DNA of plywood would be more degraded by its making process such as heating than those of veneer and sawn timber.

\section{Conservation perspective}

Imports of plywood from Malaysia and Indonesia into Japan have increased dramatically since the 1980s, and nearly 600 million $\mathrm{m}^{3}$ of plywood were imported in 2002, according to Itoh et al. (2004). However, the proportion of Red Meranti in the surface layers of the plywood imported into Japan reportedly fell from $94.9 \%$ in 1994 to $0.4 \%$ in 2000 . A large fraction of this apparent decline seems to have been due to false customs declarations, prompted by the higher tax rate imposed on Red Meranti wood. When the possibility of discriminating between the four woody groups of Shorea species using anatomical analyses was announced recently, there was a dramatic decline in such false declarations (Itoh et al. 2004). Therefore, if we can develop methods and a database that can be used to identify Shorea species at the species level, they should help to further reduce frequencies of false declarations and hence reduce illegal logging. Thus, the molecular classification data and methods for identifying the source species of woody products presented here may have potential for deterring illegal logging and illegal international trade in wood products not only for developed countries such as Japan but also the other countries such as exporters of Malaysia and Indonesia. Especially, the developed database may work for conservation of protected Shorea species and endangered Shorea species (Saw and Sam 2000). The DNA extraction methods from plywood samples should be developed more convenient and simple one because ca. $48 \%$ of exported wood products was exported as plywood in Asian countries (ITTO 2008). Consequently, these methods may help to promote the conservation of tropical forests in Southeast Asia. In future studies, it would be helpful to develop DNA markers that can be used to identify the geographical origins of individuals of each species, especially widely distributed species. For this purpose, cpDNA may be particularly suitable, because diversity is generally low within populations but high between populations. Ideally, dense cpDNA haplotype maps covering the entire distributions of each species should be compiled (Petit et al. 2002).

Acknowledgments The authors would like to thank members of the Genetic Lab at FRIM and Misako Koshiba for their assistance during sample collection and in the laboratory. We also thank Eyen Khoo of the Forest Research Centre, Sabah, Tatsuyuki Seino of University of Tsukuba, and Kanehiro Kitayama of Kyoto University, for collecting samples. Maruhi Co. Ltd. and Key Tec Co. Ltd kindly provided veneer samples. We also thank two anonymous reviewers for useful comments and suggestions in early version of this manuscript. This study was supported by a grant for the Classification of Tropical Woody Species awarded by the Forestry and Forest Products Research Institute, a Grant-in-Aid for Scientific Research (No. 18255010) provided by the Ministry of Education, Culture, Sports, Science and Technology of Japan and the Global Environment Research Program supported by the Ministry of Environment in Japan, grant no. E-091.

\section{References}

Álvarez I, Wendel JF (2003) Ribosomal ITS sequences and plant phylogenetic inference. Mol Phyl Evol 29:417-434

Ashton PS (1982) Flora Malesiana. Series I-Spermatophyta. Flowering Plants Vol. 9, part 2, Dipterocarpaceae. Martinun Nijhoff Publishers, The Netherlands

Balmford A, Bennun L, Brink B, Cooper D, Côté IM, Crane P, Dobson A, Dudley N, Dutton I, Green RE, Gregory RD, Harrison J, Kennedy ET, Kremen C, Leader-Williams N, Lovejoy TE, Mace G, May R, Mayaux P, Morling P, Phillips J, Redford K, Ricketts TH, Rodríguez JP, Sanjayan M, Schei PJ, van Jaarsveld AS, Walther BA (2005) The convention on biological diversity's 2010 target. Science 307:212-213

Cao C-P, Gailing O, Siregar I, Indrioko S, Finkeldey R (2006) Genetic variation at AFLPs for the Dipterocarpaceae and its 
relation to molecular phylogenies and taxonomic subdivisions. J Plant Res 119:553-558

Dayanandan S, Ashton PS, Williams SM, Primack RB (1999) Phylogeny of the tropical tree family Dipterocarpaceae based on nucleotide sequences of the chloroplast $r b c \mathrm{~L}$ gene. Am J Bot 86:1182-1190

Deguilloux MF, Pemonge MH, Petit RJ (2002) Novel perspectives in wood certification and forensics: dry wood as a source of DNA. Proc R Soc Lond Ser B Biol Sci 269:1039-1104

Deguilloux MF, Pemonge MH, Petit RJ (2004) DNA-based control of oak wood geographic origin in the context of the cooperage industry. Ann For Sci 61:97-104

Demesure B, Sodzi N, Petit RJ (1995) A set of universal primers for amplification of polymorphic non-coding regions of mitochondrial and chloroplast DNA in plants. Mol Ecol 4:129-131

Desch HE (1941) Dipterocarp timbers of the Malay Peninsula. Malayan Forest Records No. 14, pp 171

Felsenstein J (1985) Confidence limits on phylogenies: an approach using the bootstrap. Evolution 39:783-791

Indrioko S, Gailing O, Finkeldey R (2006) Molecular phylogeny of Dipterocarpaceae in Indonesia based on chloroplast DNA. Plant Syst Evol 261:99-115

Ishiyama H, Kado T, Iwasaki M, Ab Shukor N, Szmidt AE, Yamazaki $\mathrm{T}$ (2003) Nucleotide variation in the GapC region of four species of Shorea and its putative hybrids. Tropics 13:89-99

Itoh S, Shibata M, Kumazawa T, Abe H, Fujii T, Ogata K (2004) Proportion of Red Meranti used as surface of veneers within imported plywood in Japan. Mokuzai Kogyo (Wood Industry) 59:217-220 (in Japanese)

ITTO (2008) Annual review and assessment of the world timber situation 2008

Kajita T, Kamiya K, Nakamura K, Tachida H, Wickneswari R, Tsumura Y, Yoshimaru H, Yamazaki T (1998) Molecular phylogeny of Dipterocarpaceae in Southeast Asia based on nucleotide sequences of $m a t \mathrm{~K}$, $\operatorname{trn} \mathrm{L}$ intron, and $\operatorname{trn} \mathrm{L}-\operatorname{trn} \mathrm{F}$ intergenic spacer region in chloroplast DNA. Mol Phyl Evol 10:202-209

Kamiya K, Harada K, Kajita T, Yamazaki T, Lee HS, Ogino K, Ashton PS (1998) Molecular phylogeny of dipterocarp species using nucleotide sequences of two noncoding regions in chloroplast DNA. Tropics 7:195-207

Kamiya K, Harada K, Tachida H, Ashton PS (2005) Phylogeny of $P g i \mathrm{C}$ gene in Shorea and its closely related genera (Dipterocarpaceae), the dominant trees in Southeast Asian tropical rain forests. Am J Bot 92:775-788

Liepelt S, Sperisen C, Deguilloux M-F, Petit RJ, Kissling R, Spencer M, De Beaulieu J-L, Taberlet P, Gielly L, Ziegenhagen B (2006) Authenticated DNA from ancient wood remains. Ann Bot 98:1107-1111

Ogata K, Fujii T, Abe H, Baas P (2008) Identification of the timbers of Southeast Asia and the Western Pacific. Kaiseisha Press, Ohtsu, Japan, p 400

Parducci L, Suyama Y, Lascoux M, Bennett KD (2005) Ancient DNA from pollen: a genetic record of population history in Scots pine. Mol Ecol 14:2873-2882

Petit RJ, Brewer S, Bordács S, Burg K, Cheddadi R, Coart E, Cottrell J, Csaikl UM, van Dam B, Deans JD, Espinel S, Fineschi S, Finkeldey R, Glaz I, Goicoechea PG, Jensen JS, König AO, Lowe AJ, Madsen SF, Mátyás G, Munro RC,
Popescu F, Slade D, Tabbener H, de Vries SGM, Ziegenhagen B, de Beaulieu J-L, Kremer A (2002) Identification of refugia and post-glacial colonization routes of European white oaks based on chloroplast DNA and fossil pollen evidence. For Ecol Manage 156:49-74

Rachmayanti Y, Leinemann L, Galling O, Finkeldey R (2009) DNA from processed and unprocessed wood: factors influencing the isolation success. Forensic Sci Int Genet 3:185-192

Régis M, Lerbs-Mache S (2001) Chloroplast genetic system of higher plants: chromosome replication, chloroplast division and elements of the transcriptional apparatus. Curr Sci 80:217-224

Saitou N, Nei M (1987) A neighbor-joining method: a new method for constructing phylogenetic trees. Mol Biol Evol 4:406-425

Saw LG, Sam YY (2000) Conservation of Dipterocarpaceae in Peninsular Malaysia. J Trop For Sci 12:593-615

Soltis DE, Soltis PS (1998) Choosing an approach and an appropriate gene for phylogenetic analysis. In: Soltis DE, Soltis PS (eds) Molecular systematics of plants, DNA sequencing. Kluwer, Massachusetts, pp 1-42

Symington CF (1943) Malayan forest records no. 16. Foresters' manual of dipterocarps (reprinted with plates and historical introduction, University of Malaya Press, Kuala Lumpur, 1974)

Taberlet P, Gielly L, Pautou G, Bouvet J (1991) Universal primers for amplification of three non-coding regions of chloroplast DNA. Plant Mol Biol 17:1105-1109

Takahashi T, Tani N, Niiyama K, Yoshida S, Taira H, Tsumura Y (2008) Genetic succession and spatial genetic structure in a natural old growth Cryptomeria japonica forest revealed by nuclear and chloroplast microsatellite markers. For Ecol Manage 255:2820-2828

Tamura K, Dudley J, Nei M, Kumar S (2007) MEGA4: molecular evolutionary genetics analysis (MEGA) software version 4.0. Mol Biol Evol 24:1596-1599

Tani N, Tsumura Y, Sato H (2003) Nuclear gene sequences and DNA variation of Cryptomeria japonica samples from the post-glacial period. Mol Ecol 12:859-868

Thompson JD, Gibson TJ, Plewniak F, Jeanmougin F, Higgins DG (1997) The Clustal-X windows interface: flexible strategies for multiple sequence alignment aided by quality analysis tools. Nucleic Acids Res 25:4876-4882

Tsumura Y, Kawahara T, Wickneswari R, Yoshimura K (1996) Molecular phylogeny of Dipterocarpaceae in Southeast Asia using PCR-RFLP analysis of chloroplast genes. Theor Appl Genet 93:22-29

Vallone PM, Just RS, Coble MD, Butler JM, Parsons TJ (2004) A multiplex allele-specific primer extension assay for forensically informative SNPs distributed throughout the mitochondrial genome. Int J Legal Med 118:147-157

Viana V, Ervin J, Donovan R, Elliot C, Gholz H (eds) (1996) Certification of forest products: issues and perspectives. Island Press, Washington, DC

Soerianegara I, Lemmens RHMJ (eds) (1994) PROSEA; plant resources of South-East Asia 5, (1) timer tree: major commercial timbers. Prosea Foundation, Bogor, Indonesia, pp 610

Yulita KS, Bayer RJ, West JG (2005) Molecular phylogenetic study of Hopea and Shorea (Dipterocarpaceae): evidence from the $\operatorname{trn} \mathrm{L}-\operatorname{trn} \mathrm{F}$ and internal transcribed spacer regions. Plant Species Biol 20:167-182 